\title{
PENGARUH PERILAKU KONSUMEN TERHADAP KEPUTUSAN PEMBELIAN PISANG GORENG KIPAS KUANTAN - II KOTA PEKANBARU
}

\author{
Nenny Rapita Manurung1, Asgami Putri² \\ Program Studi Agribisnis, Universitas Lancang Kuning \\ nennyrapita16@gmail.com
}

\begin{abstract}
ABSTRAK
Penelitian ini bertujuan untuk: 1.Untuk mengetahui pengaruh perilaku konsumen terhadap keputusan pembelian pisang goreng kipas kuantan - II Kota Pekanbaru, 2. Untuk mengetahui pengaruh bauran pemasaran terhadap keputusan pembelian pisang goreng kipas kuantan - II Kota Pekanbaru.

Metode yang digunakan dalam penelitian ini adalah metode deskriptif dan verikatif dengan mengambil sampel sebanyak 100 orang dengan menggunakan teknik accidental random sampling. Analisis data yang digunakan dalam penelitian ini ialah analisis faktor.

Hasil penelitian menunjukkan bahwa 5 faktor dan 11 variabel yaitu faktor sosial yaitu pada variabel teman dan keluarga, faktor produk yaitu bentuk pisang goreng kipas, ukuran pisang goreng kipas, rasa pisang goreng kipas, aroma pisang goreng kipas, faktor individu yaitu tingkat pendapatan dan tingkat pendidikan, faktor tempat yaitu pelayanan penjual, faktor harga yaitu daya saing harga pisang goreng kipas dan harga pisang goreng kipas. Sedangkan, Faktor - faktor yang mempengaruhi bauran pemasaran terhadap keputusan pembelian pisang goreng kipas Kuantan- II Kota Pekanbaru ialah, faktor harga ialah harga pisang goreng kipas dan daya saing harga pisang goreng kipas karena harga yang ditawarkan sesuai dengan manfaat. Kesemua variabel harus dapat dipahami oleh pengelola / pendiri usaha dalam mengembangkan usaha dan semakin memotivasi untuk berinovsi supaya dapat bersaing.

Kata Kunci : Keputusan Pembelian, Pisang Goreng Kipas, Perilaku Konsumen
\end{abstract}

\section{PENDAHULUAN}

Usaha agroindustri pisang goreng kipas termasuk kedalam agroindustri makanan dengan bahan baku utama pisang. Kegiatan ini merupakan usaha tradisional yang banyak dilakukan oleh masyarakat dan telah berkembang sejak lama. Pisang merupakan salah satu produk unggulan di Indonesia. Pisang goreng kipas adalah makanan ringan yang paling banyak diproduksi dan diperdagangkan di Indonesia. Usaha agroindustri pisang goreng kipas di Pekanbaru sangat banyak maka dibutuhkan Inovasi. Kepuasan konsumen merupakan salah satu kunci keberhasilan suatu usaha, hal ini dikarenakan dengan memuaskan konsumen, badan usaha/ perusahaan dapat meningkatkan pendapatan (profit) dan mendapatkan pangsa pasar yang lebih luas.

113 Pengaruh Perilaku Konsumen Terhadap Keputusan Pembelian Pisang Goreng Kipas Kuantan - Ii Kota Pekanbaru 


\section{METODOLOGI PENELITIAN}

Penelitian ini dilaksanakan pada usaha pisang goreng kipas kuantan - II dijalan Kuantan Raya F No-6 Kelurahan Sekip Kecamatan Lima Puluh Kota Pekanbaru. Penentuan lokasi ini di lakukan secara sengaja (purposive).

Populasi dalam penelitian ini adalah konsumen yang membeli pisang goreng kipas di Kuantan - II Kota Pekanbaru. Pengambilan sampel konsumen dalam penelitian ini sebanyak 100 orang dengan menggunakan teknik Accidental Random Sampling.

Analisis faktor merupakan metode analisis multivariat. Analisis faktor adalah sebuah teknik yang digunakan untuk mencari faktor-faktor yang mampu menjelaskan hubungan atau korelasi antara berbagai indikator independen yang diobservasi.

Menurut Simamora (2005) dalam tulisan Siswati, latifa.Dkk (2017) Terdapat dua cara yang dapat dipergunakan dalam melakukan analisis faktor khususnya koefisien skor faktor, yaitu Principal component analysis (PCA) dan Common factor analysis (CFA).

\section{Bartletts test of sphericity}

Uji Bartletts test of sphericity bertujuan untuk mengetahui apakah terdapat hubungan antar variabel dalam kasus multivariat.

1. Kaiser Meyer Olkin (KMO) merupakan suatu indeks yang dipergunakan untuk meneliti ketepatan analisis faktor. Analisis faktor dikatakan tepat apabila nilai KMO berkisar antara 0,5 sampai 1,0 dan sebaliknya jika nilai KMO kurang dari 0,5 berarti analisis faktor tidak tepat.

2. Measure of Sampling Adequacy (MSA) yaitu suatu indeks perbandingan antara koefisien korelasi parsial untuk setiap variabel. Statistik Measure of Sampling Adequacy adalah sebagai berikut:

Secara matematis model dari analisis faktor adalah sebagai berikut:

$$
\mathrm{Yi}=\mathrm{Wi1X} 1+\mathrm{Wi2X} 2+\ldots . .+\mathrm{WinXn}
$$

Dimana :

Yi : Estimasi faktor ke-i

Wi : Bobot atau Koefiien skor faktor

114 Pengaruh Perilaku Konsumen Terhadap Keputusan Pembelian Pisang Goreng Kipas Kuantan - Ii Kota Pekanbaru 
$\mathrm{Xn}$

:Variabel perilaku terhadap keputusan pembelian pisang goreng kipas yang diamati

Variabel perilaku $(\mathrm{X})$ terhadap keputusan pembelian (Y) pisang goreng kipas yang diamati adalah: Variabel terikat yaitu faktor produk yang terdiri (X1) Bentuk pisang goreng kipas (X2) Ukuran pisang goreng kipas (X3) Rasa pisang goreng kipas (X4) Aroma pisang goreng kipas. Faktor hargayang terdiri dari (X5) Harga pisang goreng kipas (X6) Daya saing harga. Faktor tempat (X7) Pelayanan penjual. Faktor individu yang terdiri dari (X8) Tingkat pendapatan, (X9) Tingkat pendidikan. Faktor sosial (X10) Teman dan (X11) Keluarga.Variabel bebas yaitu keputusan pembelian $(\mathrm{Y})$.

Penelitian ini menggunakan skala likert karena data berupa kategori yang bersifat non parametrik. Penggunaan skala likert sudah terbukti mudah dimengerti oleh responden dalam memberikan penilaian terhadap suatu atribut pengukuran. Skala likert bisa digunakan sebagai summated scale dan individual scale. Ketika digunakan sebagai summated scale, biasanya nilai dari setiap item akan dijumlahkan untuk mendapatkan suatu indeks penilaian. Sedangkan penggunaan skala likert sebagai skala individu digunaan untuk menjelaskan variabel laten seperti dalam analisis menggunakan principles component analysis (PCA). Skala likert merupakan teknik pengukuran sikap yang paling luas di gunakan dalam riset pemasaran. Pertanyaan yang diberikan pada responden adalah pertanyaan tertutup. Pilihan dibuat berjenjang mulai dari intensitas paling tinggi sampai paling rendah. Dalam penelitian ini penilaian skala menggunakan 1- 4 pilihan jawaban, diberikan skor 4 untuk jawaban Sangat Setuju (SS), skor 3 untuk jawaban Setuju (S), skor 2 untuk jawaban Tidak Setuju (TS), skor 1 untuk jawaban Sangat Tidak Setuju (STS).

Tabel 1 Kriteria Penilaian

\begin{tabular}{|l|l|l|}
\hline \multicolumn{2}{|c|}{ Kriteria Penilaian } & Score \\
\hline Sangat Setuju & SS & 4 \\
\hline Setuju & S & 3 \\
\hline Tidak Setuju & TS & 2 \\
\hline Sangat Tidak setuju & STS & 1 \\
\hline
\end{tabular}

Sumber : Sugiyono (2011)

115 Pengaruh Perilaku Konsumen Terhadap Keputusan Pembelian Pisang Goreng Kipas Kuantan - Ii Kota Pekanbaru 


\section{HASIL DAN PEMBAHASAN}

Perilaku konsumen dalam membeli pisang goreng kipas kuantan raya -II di Kelurahan Sekip Kecamatan Limapuluh Kota Pekanbaru, di analisis dengan menggunakan metode analisis faktor. Analisis faktor sebuah teknik yang digunakan untuk mencari faktor-faktor yang mampu menjelaskan hubungan atau korelasi antara berbagai indikator independen yang diobservasi, di dalam penelitian ini analisis faktor dapat mengidentifikasi variabel - variabel perilaku konsumen dan bauran pemasaran yang dipertimbangkan konsumen dalam mengambil keputusan pembelian pisang goreng kipas kuantan -II. Dalam analisis faktor, variabel-variabel dalam jumlah besar dikelompokan dalam sejumlah faktor yang mempunyai sifat dan karakteristik yang hampir sama, sehingga lebih mempermudah pengolahan. Pengelompokan dilakukan dengan mengukur korelasi sekumpulan variabel dan selanjutnya menempatkan varibelvariabel yang berkorelasi tinggi dalam satu faktor, dan variabel-variabel lain yang mempunyai korelasi relatif lebih rendah ditempatkan pada faktor yang lain.

Tujuan analisis faktor akan tercapai jika dilakukan melalui prosedur yang benar. Prosedur dalam melakukan analisis ini adalah pemilihan variabel, pembentukan faktor, menginterpretasikan hasil analisis dan melakukan validasi terhadap hasil pemfaktoran. Faktor perilaku kunsumen meliputi Individu dan Sosial. Faktor bauran pemasaran meliputi produk, harga dan tempat. Variabel perilaku konsumen pada faktor individu yang diteliti ialah tingkat pendapatan dan tingkat pendidikan. Variabel perilaku konsumen pada faktor sosial yang diteliti ialah teman dan keluarga. Variabel faktor produk yang diteliti pada penelitian ini adalah bentuk pisang goreng kipas, ukuran pisang goreng kipas, rasa pisang goreng kipas, aroma pisang goreng kipas. Variabel pada faktor harga yang diteliti ialah harga pisang goreng kipas dan daya saing harga pisang goreng kipas. Variabel pada faktor tempat yang diteliti ialah pelayanan penjual pisang goreng kipas . Variabel - variabel tersebut dianalisis dengan menggunakan analisis faktor dengan bantuan program SPSS 17 (Statistical Product And Service Solution). 
Tabel hasil 2 KMO dan Bartlett Test

\begin{tabular}{|l|l|r|}
\hline \multicolumn{2}{|c|}{ KMO and Bartlett's Test } \\
\hline Kaiser-Meyer-Olkin Measure of Sampling Adequacy. & .635 \\
\hline Bartlett's Test of Sphericity & Approx. Chi-Square & 184.439 \\
\cline { 2 - 3 } & Df & 55 \\
\cline { 2 - 3 } & Sig. & .000 \\
\hline
\end{tabular}

Sumber : hasil output spss 17

Berdasarkan tabel diatas dapat dilihat bahwa nilai KMO adalah 0,635 menunjukkan bahwa nilainya berada diatas 0,5 sehingga syarat pertama yaitu dari sisi kecukupan data sudah terpenuhi. Syarat kedua analisis faktor ini layak apabila dalam pengujian korelasi multivariat dengan Bartlett's Test of Sphericity, Sig. Harus lebih kecil daripada alpa standar 0,05. Pada tabel diatas dapat kita lihat bahwa tingkat significantnya $0,000<0,05$ oleh sebab itu, kecukupan sampel terpenuhi dan matriks korelasi bukan matriks identitas maka variabel dan sampel yang ada pada tabel KMO dan bartlett test dapat di analisis lebih lanjut. Ketika hasil KMO nya kurang dari 0,5 maka dapat di pastikan bahwa variabel yang di gunakan tidak ada hubungan (matriks identitas ) dan harus mencari variabel yang sesuai dengan faktor yang di inginkan sehingga analisis faktor tidak dapat dilanjutkan.

\section{Measure of Sampling Adequacy (MSA)}

Measure of Sampling Adequacy (MSA) yaitu suatu indeks perbandingan antara koefisien korelasi parsial untuk setiap variabel. MSA digunakan untuk mengukur kecukupan sampel. Nilai ini dapat dilihat pada nilai anti-image correlation matriks. Jika nilai MSA lebih besar dari 0,5 maka variabel tersebut sudah memadai untuk dianalisis lebih lanjut. Apabila terdapat nilai MSA dari variabelvariabel awal yang kurang dari 0,5 harus dikelurkan satu per satu dari analisis, diurutkan dari variabel yang nilai MSA-nya terkecil dan tidak digunakan lagi dalam analisis selanjutnya.

Angka MSA dalam tabel anti image matriks, yang terdapat pada anti image correlation, menunjukkan nilai bentuk pisang goreng kipas (X1) adalah 0,609, ukuran pisang goreng kipas (X2) adalah 0,605, rasa pisang goreng kipas (X3) adalah 0,730, aroma pisang goreng kipas (X4) adalah 0,794, harga pisang goreng kipas (X5) adalah 0,647, daya saing harga pisang goreng kipas (X6) adalah

117 Pengaruh Perilaku Konsumen Terhadap Keputusan Pembelian Pisang Goreng Kipas Kuantan - Ii Kota Pekanbaru 
0,475, pelayanan penjual (X7) adalah 0,662, tingkat pendapatan (X8) adalah 0,636, tingkat pendidikan (X9) adalah 0,726, teman (X10) adalah 0,658, Keluarga (X11) adalah 0,608. Dari tabel MSA dibawah ini menunjukkan semua nilai ke 11 variabel berada diatas 0,5 hal ini menunjukkan sampelnya mencukupi dan analisis faktor dapat dilanjutkan ke tahap selanjutnya.

Tabe 3 anti image matrices

\begin{tabular}{|l|l|}
\hline Nama variabel & Nilai MSA \\
\hline Bentuk pisang goreng kipas (X1) & 0,609 \\
\hline Ukuran pisang goreng kipas (X2) & 0,605 \\
\hline Rasa pisang goreng kipas (X3) & 0,730 \\
\hline Aroma pisang goreng kipas (X4) & 0,794 \\
\hline Harga pisang goreng kipas (X5) & 0,647 \\
\hline Daya saing harga pisang goreng kipas (X6) & 0,475 \\
\hline Pelayanan penjual pisang goreng kipas (X7) & 0,662 \\
\hline Tingkat pendaptan (X8) & 0,636 \\
\hline Tingkat pendidikan (X9) & 0,726 \\
\hline Teman (X10) & 0,658 \\
\hline Keluarga (X11) & 0,608 \\
\hline
\end{tabular}

Sumber: Hasil output SPSS 17

Usaha bapak yana patriana digemari oleh banyak konsumen karena usaha ini selektif dalam pemilihan bahan baku sehingga mampu menghasilkan produk yang berkualitas sehingga menyeimbangkan kualitas dengan harga yang ditawarkan kepada konsumen hal ini membuat konsumen merasa puas dengan apa yang mereka beli bahkan konsumen rela mengantri untuk mendapat pisang goreng kipas kuantan - II sebelum persediaannya habis khususnya pisang goreng kipas dengan $1 / 2$ matang karena mereka dapat menggoreng sendiri dirumah jika mereka tidak percaya dengan pisang goreng kipas yang sudah siap saji. Daya tarik lainnya karena konsumen diberikan diskon jika pembeliannya dalam jumlah yang banyak. Pada tabel dibawah dapat kita lihat yang mempunyai pengaruh paling kecil ialah tingkat pendidikan dengan nilai 0,345 hal ini dikarenakan memakan pisang goreng kipas dapat di konsumsi oleh siapa saja, dimana saja, dan kapan saja tanpa membeda-bedakan kelas sosial mayarakat, dengan kata lain produk ini dapat di jual belikan secara mudah dan praktis

118 Pengaruh Perilaku Konsumen Terhadap Keputusan Pembelian Pisang Goreng Kipas Kuantan - Ii Kota Pekanbaru 
Tabel 4 Communalities

\begin{tabular}{|l|r|r|}
\hline \multicolumn{3}{|c|}{ Communalities } \\
\hline \multicolumn{1}{|c|}{ Initial } & \multicolumn{1}{|c|}{ Extraction } \\
\hline bentuk pisang goreng kipas & 1.000 & .678 \\
\hline ukuran pisang goreng kipas & 1.000 & .744 \\
\hline rasa pisang goreng kipas & 1.000 & .679 \\
\hline aroma pisang goreng kipas & 1.000 & .367 \\
\hline harga pisang goreng kipas & 1.000 & .631 \\
\hline daya saing harag pisang goreng kipas & 1.000 & .758 \\
\hline pelayanan penjual pisang goreng kipas & 1.000 & .541 \\
\hline tingkat pendapatan & 1.000 & .600 \\
\hline tingkat pendidikan & 1.000 & .345 \\
\hline Teman & 1.000 & .667 \\
\hline KePluarga & 1.000 & .672 \\
\hline Extraction Method: Principal Component Analysis. \\
\hline
\end{tabular}

Sumber: Hasil output SPSS 17

Pada tabel 14 total variance explained dibawah dapat dilihat bahwa terdapat 11 variabel (component) yang di masukkan ke dalam analisis faktor. Terdapat 4 faktor yang terbentuk, component 1 berada pada posisi 2, kemudian component 2 , component 3 dan component 4 berada diatas 1. Dapat disimpulkan terdapat 1 fakor yang diatas 2 dan 3 faktor diatas 1 . Dengan demikian terdapat 4 faktor yang posisinya berada >1 ( memiliki hubungan yang erat dengan faktor yang terbentuk) sedangkan 7 faktor lagi posisinya berada dibawah satu (hubungannya tidak erat dengan faktor yang terbentuk ).

Tabel 5 Total Variance Explained

\begin{tabular}{|c|c|c|c|c|c|c|}
\hline \multicolumn{7}{|c|}{ Total Variance Explained } \\
\hline \multirow[b]{2}{*}{ Component } & \multicolumn{3}{|c|}{$\begin{array}{c}\text { Initial } \\
\text { Eigenvalues }\end{array}$} & \multicolumn{3}{|c|}{$\begin{array}{c}\text { Extraction Sums of Squared } \\
\text { Loadings }\end{array}$} \\
\hline & Total & $\begin{array}{c}\% \text { of } \\
\text { Variance }\end{array}$ & $\begin{array}{c}\text { Cumulative } \\
\%\end{array}$ & Total & $\begin{array}{c}\% \text { of } \\
\text { Variance }\end{array}$ & $\begin{array}{c}\text { Cumulative } \\
\%\end{array}$ \\
\hline 1 & 2.683 & 24.387 & 24.387 & 2.683 & 24.387 & 24.387 \\
\hline 2 & 1.592 & 14.468 & 38.855 & 1.592 & 14.468 & 38.855 \\
\hline 3 & 1.300 & 11.815 & 50.670 & 1.300 & 11.815 & 50.670 \\
\hline 4 & 1.108 & 10.075 & 60.745 & 1.108 & 10.075 & 60.745 \\
\hline 5 & .920 & 8.360 & 69.105 & & & \\
\hline
\end{tabular}

119 Pengaruh Perilaku Konsumen Terhadap Keputusan Pembelian Pisang Goreng Kipas Kuantan - Ii Kota Pekanbaru 


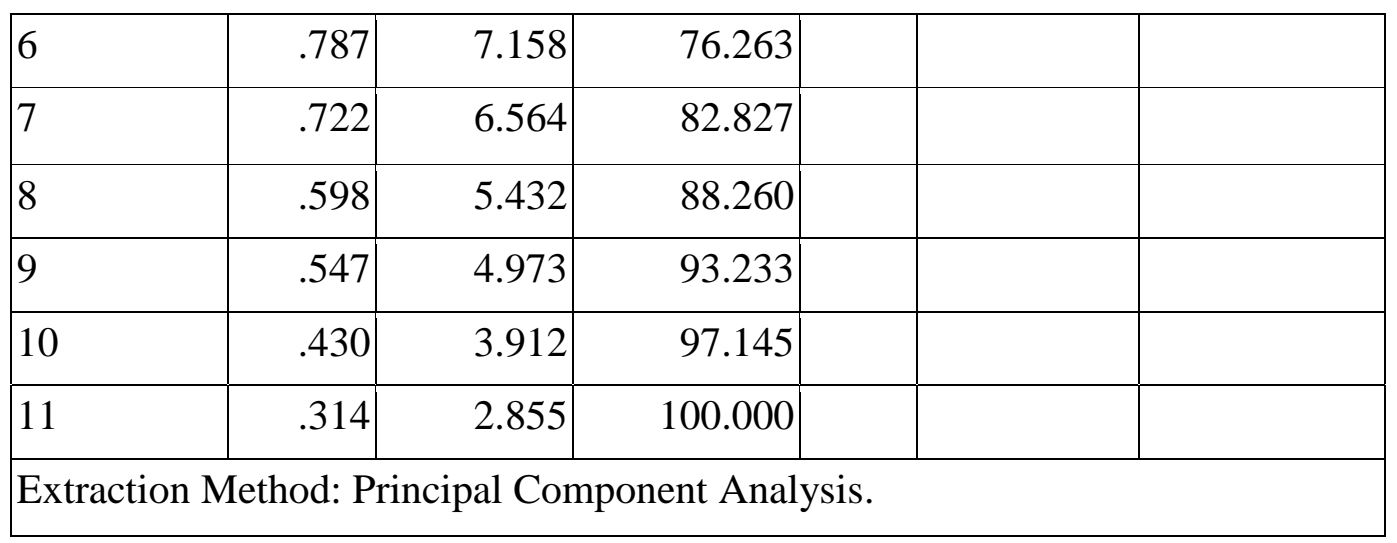

Sumber: Hasil output SPSS 17

Tabel 6 Component Matrix

\begin{tabular}{|l|r|r|r|r|}
\hline \multicolumn{5}{|c|}{ Component Matrix ${ }^{\mathbf{2}}$} \\
\hline & \multicolumn{3}{|c|}{ Component } \\
\hline & \multicolumn{1}{|c|}{1} & \multicolumn{1}{|c|}{2} & \multicolumn{1}{c|}{3} & \multicolumn{1}{c|}{4} \\
\hline bentuk pisang goreng kipas & .637 & -.392 & -.076 & -.336 \\
\hline ukuran pisang goreng kipas & .645 & -.545 & -.158 & .083 \\
\hline rasa pisang goreng kipas & .460 & -.186 & -.080 & -.653 \\
\hline aroma pisang goreng kipas & .494 & -.291 & .091 & .172 \\
\hline harga pisang goreng kipas & .506 & -.008 & .577 & .205 \\
\hline daya saing harag pisang goreng kipas & .302 & .097 & .811 & -.012 \\
\hline pelayanan penjual pisang goreng kipas & .338 & .593 & .189 & -.199 \\
\hline tingkat pendapatan & .451 & -.125 & -.238 & .569 \\
\hline tingkat pendidikan & .419 & .208 & -.143 & .324 \\
\hline Teman & .497 & .605 & -.225 & .055 \\
\hline Keluarga & .564 & .485 & -.317 & -.137 \\
\hline Extraction Method: Principal Component Analysis. & & & \\
\hline a. 4 components extracted. & & & \\
\hline
\end{tabular}

Sumber : hasil output SPSS 17

- Kondisi bentuk pisang goreng kipas sebagai berikut :

1. Korelasi antara bentuk pisang goreng kipas dengan faktor 1 adalah 0,637 (sangat kuat karena berada diatas 0,5)

2. Korelasi antara bentuk pisang goreng kipas dengan faktor 2 adalah - 0,392 (sangat lemah karena berada dibawah 0,5)

3. Korelasi antara bentuk pisang goreng kipas dengan faktor 3 adalah - 0,076 ( sangat lemah karena berada di bawah 0,5)

4. Korelasi antara bentuk pisang goreng kipas dengan faktor 4 adalah - 0,336

120 Pengaruh Perilaku Konsumen Terhadap Keputusan Pembelian Pisang Goreng Kipas Kuantan - Ii Kota Pekanbaru 
(sangat lemah karena berada di bawah 0,5). Demikian selanjutnya untuk variabel lainnya.

Component matrix hasil proses rotasi (rotated component matrix) memperlihatkan distribusi variabel yang lebih jelas dan nyata. Terlihat bahwa sekarang faktor loading yang dulunya kecil semakin kecil semakin diperkecil, dan factor loading yang besar semakin diperbesar.

Tabel 7 Rotated Component Matrix

\begin{tabular}{|l|r|r|r|r|}
\hline \multicolumn{5}{|c|}{ Rotated Component Matrix } \\
\hline & \multicolumn{5}{|c|}{ Component } \\
\hline & \multicolumn{1}{|c|}{1} & \multicolumn{1}{|c|}{2} & 3 & \multicolumn{1}{c|}{4} \\
\hline bentuk pisang goreng kipas & .052 & .784 & .227 & .098 \\
\hline ukuran pisang goreng kipas & -.093 & .599 & .611 & .054 \\
\hline rasa pisang goreng kipas & .167 & .790 & -.167 & .017 \\
\hline aroma pisang goreng kipas & -.030 & .302 & .457 & .256 \\
\hline harga pisang goreng kipas & .090 & .093 & .278 & .733 \\
\hline daya saing harag pisang goreng kipas & .040 & .037 & -.084 & .865 \\
\hline pelayanan penjual pisang goreng kipas & .634 & .020 & -.198 & .315 \\
\hline tingkat pendapatan & .123 & -.019 & .765 & -.018 \\
\hline tingkat pendidikan & .384 & -.047 & .438 & .058 \\
\hline Teman & .797 & -.007 & .178 & .010 \\
\hline Keluarga & .774 & .225 & .129 & -.076 \\
\hline
\end{tabular}

Extraction Method: Principal Component Analysis.

Rotation Method: Varimax with Kaiser Normalization.

a. Rotation converged in 8 iterations.

Sumber : hasil output SPSS 17

Dari tabel 7 Component Transformation Matrix dibawah dapat dijelaskan bahwa pada diagonal faktor (component) $1,2,3,4 \quad(0,505 ;-0,475 ;-0,254$, 0,091). Angka dengan ditandai minus (-) hal tersebut menunjukkan arah korelasi. Sedangkan pada diagonal yang lain menunjukkan angka dibawah 0,5 yang menunjukkan adanya terdapat komponen lain pada masing - masing faktor yang mempunyai korelasi lebih tinggi. Hanya 1 faktor yang angkanya diatas 0,5, yaitu faktor 1 (faktor produk).

Berdasarkan terbentuknya, terdapat 1 faktor saja yang nilai diagonal diatas 0,5, hal itu sudah cukup untuk mewakili faktor - faktor yang telah terbentuk dalam keputusan konsumen untuk membeli pisang goreng kipas. Setelah

121 Pengaruh Perilaku Konsumen Terhadap Keputusan Pembelian Pisang Goreng Kipas Kuantan - Ii Kota Pekanbaru 
melakukan faktoring dan rotasi, langkah atau tahap selanjutnya adalah menginterpretasikan faktor yang telah terbentuk. Hal ini dilakukan agar bisa mewakili variabel - variabel anggota faktor tersebut. Menurut Zaini Hasan dalam Fajar S.Saputro (2007), mengatakan pemberian nama dan konsep tiap faktor ditentukan berdasarkan makna umum variabel yang tercakup didalamnya. faktor 1 disebut sebagai faktor produk.

Tabel 8 Component Transformation Matrix

\begin{tabular}{|l|r|r|r|r|}
\hline \multicolumn{5}{|c|}{ Component Transformation Matrix } \\
\hline Component & 1 & 2 & 3 & 4 \\
\hline 1 & .505 & .581 & .531 & .353 \\
\hline 2 & .823 & -.475 & -.306 & .064 \\
\hline 3 & -.239 & -.124 & -.254 & .929 \\
\hline 4 & -.104 & -.649 & .748 & .091 \\
\hline Extraction Method: Principal Component Analysis. \\
Rotation Method: Varimax with Kaiser Normalization. \\
\hline
\end{tabular}

Sumber : hasil output SPSS 17

\section{KESIMPULAN}

Berdasarkan hasil penelitian dan pembahasan yang dilakukan, maka dapat disimpulkan sebagai berikut Masyarakat Kota Pekanbaru dalam melakukan keputusan pembelian camilan pisang goreng mempertimbangkan berbagai faktor. Adapun faktor yang dipertimbangkan meliputi 5 faktor yaitu faktor sosial faktor produk, , faktor individu, faktor tempat, faktor harga.

1. Faktor - faktor yang mempengaruhi perilaku konsumen terhadap keputusan pembelian pisang goreng kipas Kuantan - II Kota Pekanbaru ialah faktor sosial yaitu pada variabel teman dan keluarga, faktor produk yaitu bentuk pisang goreng kipas, ukuran pisang goreng kipas, rasa pisang goreng kipas, aroma pisang goreng kipas, faktor individu yaitu tingkat pendapatan dan tingkat pendidikan, faktor tempat yaitu pelayanan penjual, faktor harga yaitu daya saing harga pisang goreng kipas dan harga pisang goreng kipas. Ke lima faktor dan 11 variabel mempunyai pengaruh terhadap keputusan pembelian pisang goreng kipas sehingga seorang pengusaha harus memperhatikan hal ini supaya memperoleh keuntungan yang besar.

122 Pengaruh Perilaku Konsumen Terhadap Keputusan Pembelian Pisang Goreng Kipas Kuantan - Ii Kota Pekanbaru 
2. Faktor - faktor yang mempengaruhi bauran pemasaran terhadap keputusan pembelian pisang goreng kipas Kuantan- II Kota Pekanbaru ialah , faktor harga ialah daya saing harga pisang goreng kipas, konsumen merasa puas dengan harga yang ditawarkan oleh pengusaha karena jika dibandingkan dengan harga pisang goreng kipas ditempat lain sangat berbeda, Bapak yana patriana membuat harga sudah dikondisikan dengan manfaat yang di peroleh melalui kualitas yang terjamin bersih dan pelayanan yang di lakukan juga baik.

\section{DAFTAR PUSTAKA}

Siswati Latifa,dkk. 2017.Analisis Factor Yang Mempengaruhi keputusan Pembelian Ikan Oleh Masyarakat Di Kecamatan Tenayan Kota Pekanbaru. Fakultas Pertanian Universitas Lancang Kuning

Santoso, singgih. 2004. SPSS Statistik Multivariat. Jakarta. PT. Elex Media Komputindo.

Sugiyono.2011. Metode Penelitan Kuantitatif Kualitatif Dan Kombinasi (Mixed Methods). Bandung :AlfSabeta. 